\title{
ELECTROSYNTHESIS OF Ni-Co/HYDROXYAPATITE AS A CATALYST FOR HYDROGEN GENERATION VIA THE HYDROLYSIS OF AQUEOUS SODIUM BOROHYDRIDE $\left(\mathrm{NaBH}_{4}\right)$ SOLUTIONS
}

\author{
Adrian Nur ${ }^{1, \bigotimes}$, Anatta W. Budiman ${ }^{1}$, Arif Jumari ${ }^{1}$, Nazriati Nazriati $^{2}$, \\ Fauziatul Fajaroh ${ }^{2}$
}

https://doi.org/10.23939/chcht15.03.389

\begin{abstract}
To generate hydrogen from its storage as $\mathrm{NaBH}_{4}$, a catalyst was synthesized via an electrochemical method. The catalyst, Ni-Co, had hydroxyapatite as a support catalyst. The electrochemical cell consisted of a DC power supply, a carbon anode and cathode, and a bipolar membrane to separate the cell into two chambers. The current density was adjusted to 61,91 , and $132 \mathrm{~mA} / \mathrm{cm}^{2}$. The electrolysis time was 30,60 , and $90 \mathrm{~min}$. The particles produced were analyzed by XRD and SEM/EDX and tested in the hydrolysis of $\mathrm{NaBH}_{4}$ for hydrogen generation. The $\mathrm{Ni}-\mathrm{Co} / \mathrm{HA}$ catalyst test concluded that the period of time used for electrolysis during catalyst formation was positively correlated with the rate of $\mathrm{NaBH}_{4}$ hydrolysis in the production of hydrogen. The highest rate of hydrogen production was obtained using the synthesized catalyst with a current density of $92 \mathrm{~mA} / \mathrm{cm}^{2}$. The $\mathrm{NaBH}_{4}$ hydrolysis reaction followed a first-order reaction with the rate constant of (2.220-14.117) $10^{-3} \mathrm{l} /(\mathrm{g} \cdot \mathrm{min})$. The Arrhenius equation for hydrolysis reactions within the temperature range of 300$323 \mathrm{~K}$ is $k=6.5 \cdot 10^{-6} \exp (-6000 / T)$.
\end{abstract}

Keywords: Ni-Co/hydroxyapatite, hydrogen storage, synthesis, electrochemical method, bipolar membrane.

\section{Introduction}

Hydrogen is the fuel of the future for several advantageous reasons, chief among them being availability (obtainable from renewable sources), ecofriendliness, and efficiency [1-3]. One of the challenges of developing hydrogen as a future fuel relates to storage [4]. There are several hydrogen storage methods: high-

\footnotetext{
${ }^{1}$ Department of Chemical Engineering, Sebelas Maret University, Jl. Ir. Sutami 36 A Jebres, 57126 Surakarta, Indonesia

${ }^{2}$ Department of Chemistry, Faculty of Mathematics and Science,

State University of Malang, 65111 Malang, Indonesia

adriannur@staff.uns.ac.id

(c) Nur A., Budiman A., Jumari A., Nazriati N., Fajaroh F., 2021
}

pressure or cryogenic tanks, physical sorption methods, and as a chemical hybrid. Storage of hydrogen as a chemical hydride (liquid phase) is a promising alternative due to the ease of portability and safety under ambient conditions.

$\mathrm{NaBH}_{4}$ has proven to be a useful hydrogen storage material due to its high storage capacity, high stability under ambient air, ability to be produced at low temperatures, and harmless reaction products $[5,6]$. The catalyst for hydrogen production from a chemical hydride $\left(\mathrm{NaBH}_{4}\right)$ must possess high levels activity and durability under an alkaline atmosphere. $\mathrm{Ni}$ and $\mathrm{Co}$ are transition metals that have shown excellent catalyst properties [7-9]. Catalyst support is needed to increase the dispersion of the catalyst and to prevent it from escaping with hydrogen bubbles. Hydroxyapatite provides sufficient catalyst support $[10,11]$. Electrochemical synthesis is effective for in situ metal-hydroxyapatite production which is easily controlled [12]. The Ni-Co/hydroxyapatite (HA) catalyst is used in hydride chemistry to produce hydrogen from storage as $\mathrm{NaBH}_{4}$.

The novelty of this work involves the electrochemical synthesis of the $\mathrm{Ni}-\mathrm{Co} / \mathrm{HA}$ catalyst in situ, which is further used for hydrogen production. The purpose of this work was to synthesize an electrochemical $\mathrm{Ni}-\mathrm{Co} /$ hydroxyapatite catalyst and its use in the $\mathrm{NaHB}_{4}$ hydrolysis to generate hydrogen.

\section{Experimental}

The experimental setup used for the catalyst synthesis is represented in Fig. 1. The equipment consisted of an electrochemical cell, a DC power supply (Zhaoxin PS-3005D), and a $5 \times 10 \times 10 \mathrm{~cm}$ acrylic container with $250 \mathrm{ml}$ of electrolyte solution. A bipolar membrane was used to divide the acrylic container into an anode chamber and a cathode chamber [12]. The bipolar membrane consisted of an anion exchange membrane that faced the anode chamber and a cation exchange 
membrane that faced the cathode chamber. The bipolar membrane was a Fumasep FBM that was acquired from FUMATECH BWT GmbH. The electrolyte solution consisted of $0.1 \mathrm{M} \mathrm{Ni}^{2+}, 0.1 \mathrm{M} \mathrm{Co}^{2+}, 0.25 \mathrm{M} \mathrm{Ca}^{2+}, 0.15 \mathrm{M}$ $\mathrm{PO}_{4}{ }^{3-}$, and $0.25 \mathrm{M}$ EDTA. For this solution, we dissolved $\mathrm{NiCl}_{2}, \mathrm{CoCl}_{2}, \mathrm{CaCl}_{2}, \mathrm{KH}_{2} \mathrm{PO}_{4}$, and $\mathrm{Na}_{2} \mathrm{H}_{2}$ EDTA.2 $\mathrm{H}_{2} \mathrm{O}$. All chemicals were of analytical grade and were purchased from Merck. There was no treatment before use. The anode and cathode electrodes were formed from $5.2 \times 2 \mathrm{~cm}$ plate-shaped carbon with a thickness of $0.4 \mathrm{~cm}$. The DC power supply provided the potential difference between two electrodes with current density that could be adjusted to 61,92 , and $132 \mathrm{~mA} / \mathrm{cm}^{2}$. During the electrolysis process, the $\mathrm{pH}$ of the solution was measured using a portable $\mathrm{pH}$ meter (Ohaus ST300). In addition to current density, the electrolysis time was also varied (30, 60 , and $90 \mathrm{~min}$ ). The electrochemical cell was placed in an ultrasonic cleaner acquired from Elmasonic. Electrolysis was conducted at room temperature. Furthermore, filter paper was used to separate the resultant particles from the solution, and the particles were then washed with demineralized water, and dried in an oven at $313 \mathrm{~K}$ overnight. The particles produced were analyzed by XRD and SEM/EDX. XRD analysis was carried out using a Shimadzu 6000 X-ray diffractometer (XRD) with $\mathrm{CuK} \alpha$ $(\lambda=1.5406 \mathrm{~nm})$ radiation with a step size of $0.7^{\circ} \cdot \mathrm{s}^{-1}$ over angular ranges $(2 \theta)$ from 20 to $60^{\circ}$. SEM/EDX analysis was accomplished by scanning electron microscopy (Inspect S40, FEI) using an acceleration voltage of $20 \mathrm{kV}$.

The viability of the $\mathrm{Ni}-\mathrm{Co} / \mathrm{HA}$ catalyst was tested in the hydrolysis of $\mathrm{NaBH}_{4}$ for hydrogen production. The hydrolysis reaction was carried out in a batch reactor (Fig. 2). A $0.1 \mathrm{M}$ sample from $150 \mathrm{ml}$ of a $\mathrm{NaBH}_{4}$ solution was placed in a water bath to maintain a reaction temperature that could be duplicated under various conditions that could reasonably be encountered using other catalysts and temperatures. The catalyst tested was subjected to electrolysis for $60 \mathrm{~min}$ under current densities of $61 \mathrm{~mA} / \mathrm{cm}^{2}$ (cat61mA $/ \mathrm{cm}^{2} 60 \mathrm{~min}$ ), $92 \mathrm{~mA} / \mathrm{cm}^{2}$ (cat92mA $/ \mathrm{cm}^{2} 60 \mathrm{~min}$ ), and $123 \mathrm{~mA} / \mathrm{cm}^{2}$ (cat $123 \mathrm{~mA} / \mathrm{cm}^{2} 60 \mathrm{~min}$ ). The reaction occurred at various temperatures: 300,313 and $323 \mathrm{~K}$. The formed hydrogen gas was drained into a closed tube filled with water. The water was pushed into an Erlenmeyer flask to allow measurement of its weight and volume.

\section{Results and Discussion}

The $\mathrm{pH}$ values of the solution during electrolysis in the both anode and cathode chambers are shown in Fig. 3. The solution $\mathrm{pH}$ in the anode chamber decreased from an initial value of 3.0 to near zero. The decrease in $\mathrm{pH}$ in the anode chamber occurred during the oxidation of water via electrolysis, which resulted in $\mathrm{H}^{+}$ions. The resultant $\mathrm{H}^{+}$ ions were held in the anode chamber of the bipolar membrane and caused a drop in the $\mathrm{pH}$ of the solution. An increase in the current density accelerated the decrease in the $\mathrm{pH}$ of the solution. A higher current density resulted in a faster oxidation reaction, faster production of $\mathrm{H}^{+}$ions, and a faster decrease in the $\mathrm{pH}$ of the solution. The $\mathrm{pH}$ of the solution in the cathode chamber was increased from 3 to 12 with an increase in the electrolysis time. The increase in $\mathrm{pH}$ in the cathode chamber also happened during the electrolysis process, where there was a reduction in water and $\mathrm{OH}^{-}$ions were produced. The bipolar membrane in the cathode chamber trapped the $\mathrm{OH}^{-}$ions so that the solution $\mathrm{pH}$ in the cathode chamber increased. Higher current density accelerated the increase in $\mathrm{pH}$. The larger current density accelerated the reduction reaction at the cathode, which in turn accelerated the production of $\mathrm{OH}^{-}$ions. The rapid production of $\mathrm{OH}^{-}$ions also accelerated the increase in the solution $\mathrm{pH}$.

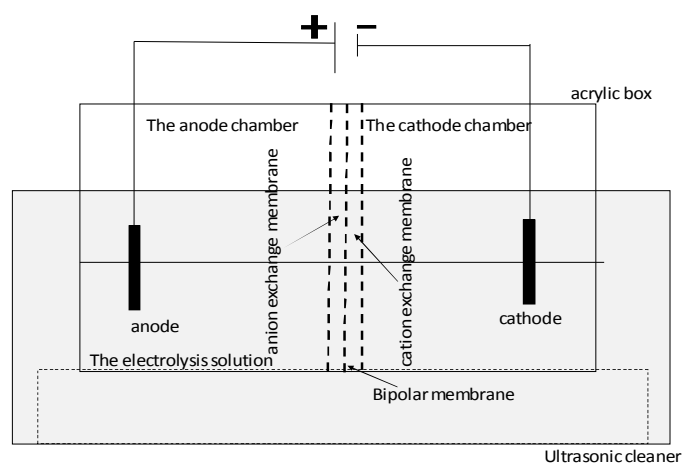

Fig. 1. Experimental setup for the catalyst synthesis

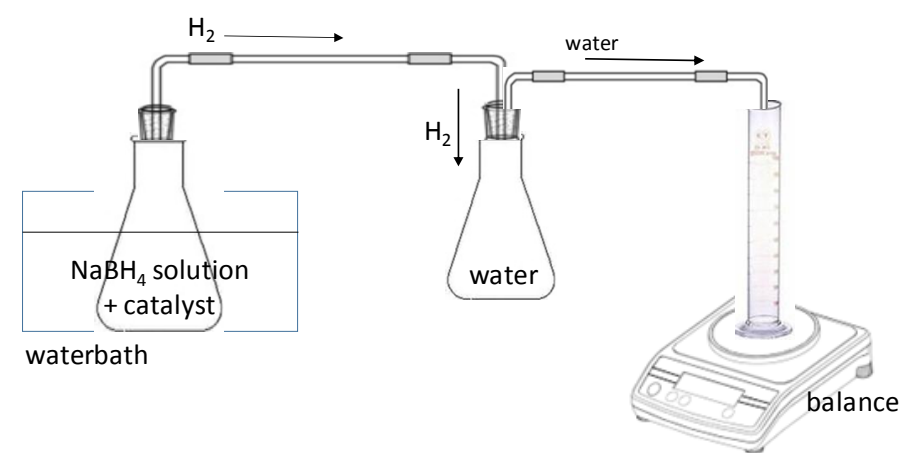

Fig. 2. Equipment for the $\mathrm{NaBH}_{4}$ hydrolysis in the production of hydrogen 


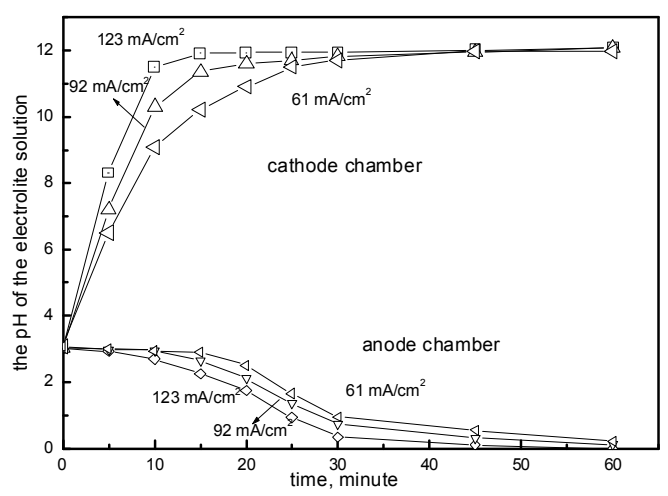

Fig. 3. The solution $\mathrm{pH}$ during electrolysis in the anode and cathode chambers

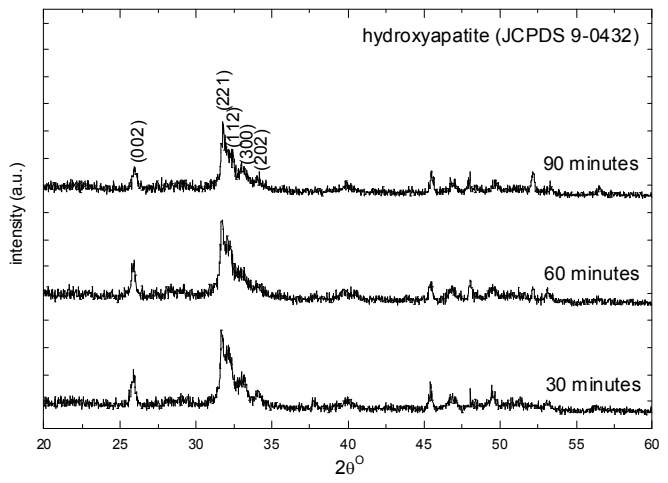

Fig. 4. XRD patterns of the particles as a result of electrolysis in the anode chamber

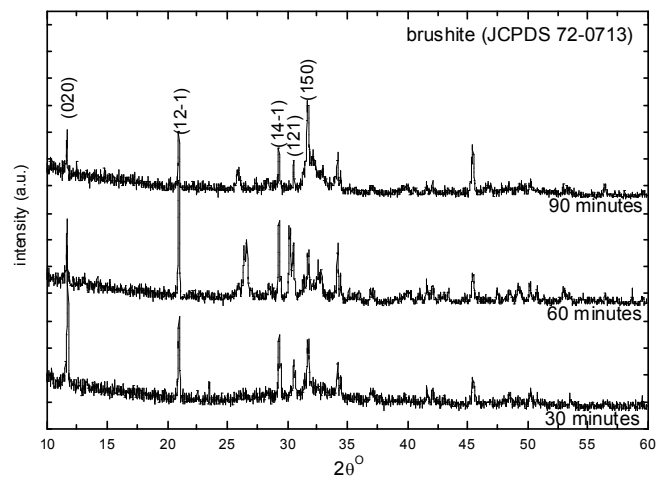

Fig. 5. XRD patterns of the particles as a result of electrolysis in the cathode chamber

Particles obtained in the anode and cathode chambers were analyzed using an X-ray diffractometer. The resultant diffraction patterns appear in Figs. 4 and 5. Fig. 4 shows the particle diffraction patterns produced by the anode chamber for electrolysis times of 30,60 , and $90 \mathrm{~min}$. The particles produced in the anode chamber at electrolysis times of 30,60 and 90 min corresponded to the brushite diffraction pattern. Brushite diffraction patterns are characterized by peaks at $11.71^{\circ}(020), 20.99^{\circ}$ $(12-1), 29.35^{\circ}(14-1), 30.53^{\circ}(121)$, and $34.21^{\circ}(150)$. The calcium phosphate that formed in the anode chamber was brushite. Brushite forms in solutions with low $\mathrm{pH}$. Based on the patterns shown in Fig. 3, the $\mathrm{pH}$ of the calcium phospate particle solution is approximated to 0 .

The diffraction patterns of the particles formed in the cathode chamber are shown in Fig. 5. HA particles formed in the cathode chamber showed the highest peaks for HA: $25.99^{\circ}(002), 28.37^{\circ}(210), 31.73^{\circ}(211)$, and $33.23^{\circ}(300)$. HA has a tendency to be formed when the solution $\mathrm{pH}$ exceeds 8 . Fig. 3 shows that the solution $\mathrm{pH}$ in the cathode chamber achieved 12 after $30 \mathrm{~min}$ of electrolysis. HA was formed in the cathode chamber due to the high $\mathrm{pH}$ of the solution.

Fig. 6 shows the reactions occurred in the anode chamber when water oxidation produced $\mathrm{H}^{+}$ions. The $\mathrm{H}^{+}$ ions lowered the solution $\mathrm{pH}$ in the anode chamber. At low $\mathrm{pH}$, calcium and phosphate reacted and formed brushite. The reactions occurred in the cathode chamber, where a water reduction reaction produced $\mathrm{OH}^{-}$ions were observed as well. The $\mathrm{OH}^{-}$ions raised the $\mathrm{pH}$ of the solution. The $\mathrm{OH}^{-}$ions shifted the chemical equilibrium of some reactions to form HA.

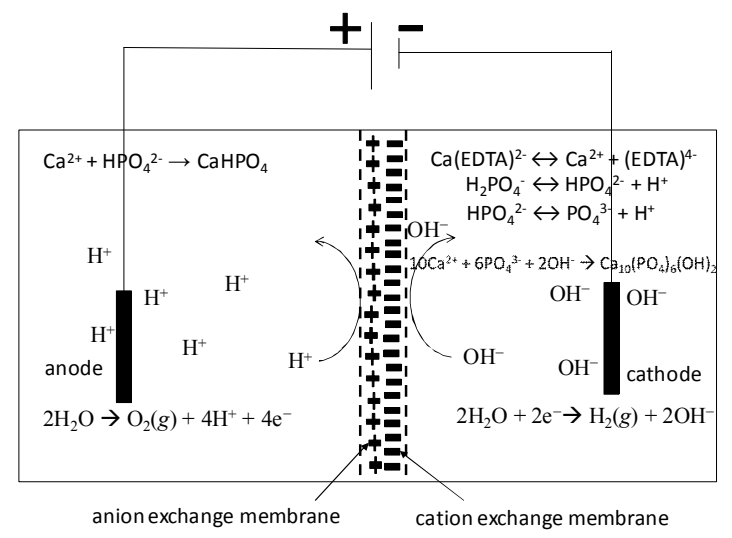

Fig. 6. Reactions that form brushite and hydroxyapatite

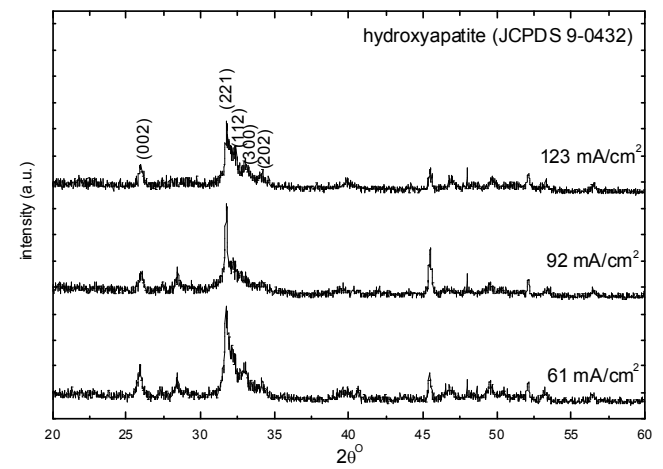

Fig. 7. XRD patterns of the particles caused by electrolysis at various current densities

The effect of current density on the calcium phosphate phase that formed is shown in Fig. 7. There 
were no significant differences in the calcium phosphate phases formed at current densities of 61, 92, and $123 \mathrm{~mA} / \mathrm{cm}^{2}$. All three of the current densities tested produced HA. The $\mathrm{pH}$ of the solution at the cathode was quite high (approximately 12). Because of the high $\mathrm{pH}$, all the calcium phosphate that formed was HA.

The SEM image (Fig. 8) shows that the particles that were formed consisted of smaller particles forming agglomerations. These small particles had irregular shapes, and particle density increased with the increase in current density.

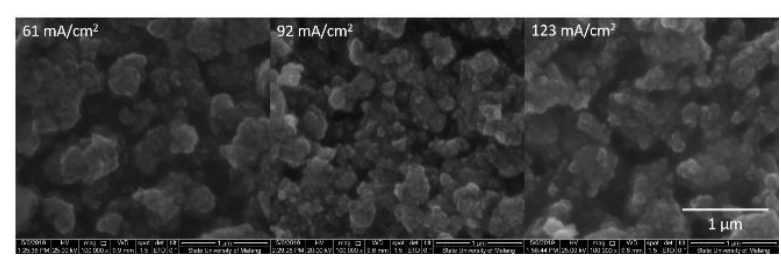

Fig. 8. Morphology of the particles produced by electrosynthesis of the $\mathrm{Ni}-\mathrm{Co} / \mathrm{HA}$ catalyst

The results of EDX analysis of particles in the anode and cathode chambers are shown in Figs. 9 and 10.

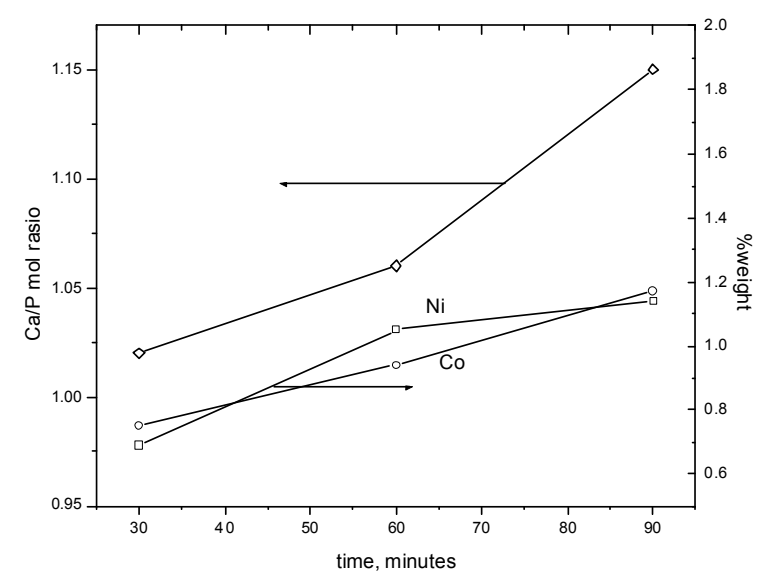

Fig. 9. Mole ratio of $\mathrm{Ca} / \mathrm{P}$ particles and $\mathrm{Ni}-\mathrm{Co}$ content in particles formed in the anode chamber

The Ni-Co/HA catalyst was used in the hydrolysis reaction of $\mathrm{NaBH}_{4}$ as a test for hydrogen production in a batch reactor. The volumes of hydrogen produced appear in Figs. 11, 12, and 13. Fig. 11 shows the volume of hydrogen generated during electrolysis for 30 and $60 \mathrm{~min}$. The volume of hydrogen produced was always increased with the increase in the reaction time. The hydrolysis reaction using a catalyst produced during $60 \mathrm{~min}$ of electrolysis was faster than that using a catalyst produced after $30 \mathrm{~min}$ of electrolysis. The catalyst produced by $60 \mathrm{~min}$ of electrolysis had higher contents of both $\mathrm{Ni}$ and Co compared with that of the catalyst produced after $30 \mathrm{~min}$ of electrolysis. Higher contents of $\mathrm{Ni}$ and $\mathrm{Co}$ in the
The mole ratio of $\mathrm{Ca} / \mathrm{P}$ particles in the anode chamber ranged from 1 to 1.15 , which agreed with the results of XRD analysis showing that the calcium phosphate phase formed brushite. A longer electrolysis time resulted in a higher mole ratio of $\mathrm{Ca} / \mathrm{P}$. The amount of $\mathrm{Ni}$ in the particles formed in the anode chamber ranged from 0.69 to $1.14 \mathrm{wt} \%$ while Co ranged from 0.75 to $1.17 \mathrm{wt} \%$. A longer electrolysis time resulted in a higher weight for $\mathrm{Ni}$ and $\mathrm{Co}$ in the particles formed in the anode chamber. Particles containing $\mathrm{Ni}$ and $\mathrm{Co}$ formed in the anode chamber even though the $\mathrm{pH}$ in the anode chamber was very low. Particles likely formed from the oxidation of nickel and cobalt which then resulted in formation of nickel oxide and cobalt oxide.

The mole ratio of $\mathrm{Ca} / \mathrm{P}$ particles in the cathode chamber ranged from 1.61 to 1.64 , which agrees with the results of XRD analysis showing that the calcium phosphate phase that formed in the cathode chamber was HA. A longer electrolysis time produced higher $\mathrm{Ca} / \mathrm{P}$ molar ratios. $\mathrm{Ni}$ content in particles formed in the cathode chamber ranged from 1.93 to $6.63 \mathrm{wt} \%$ while Co content ranged from 2.92 to $11.91 \mathrm{wt} \%$. A longer electrolysis time produced a higher content of $\mathrm{Ni}$ and $\mathrm{Co}$ in the particles.

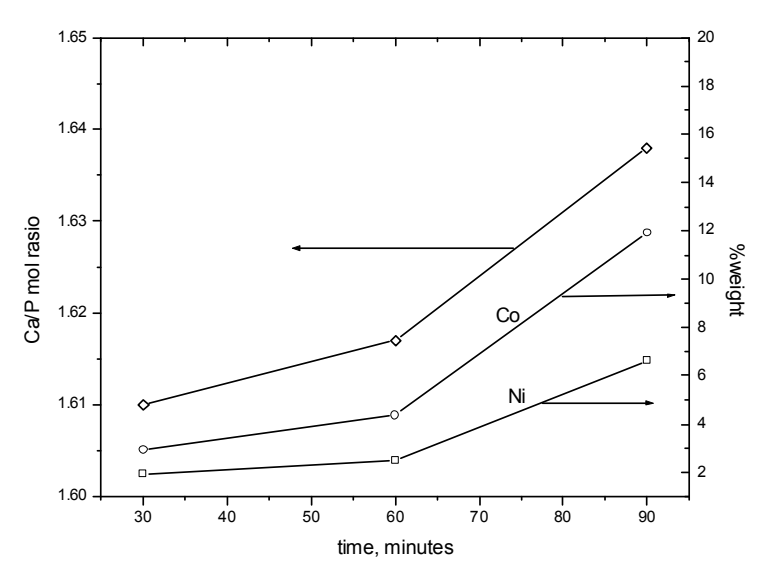

Fig. 10. Mole ratio of $\mathrm{Ca} / \mathrm{P}$ particles and Ni-Co content in particles formed in the cathode chamber

catalyst accelerated the hydrolysis of $\mathrm{NaBH}_{4}$ for hydrogen production. Comparisons of hydrogen production as a result of hydrolysis with and without catalyst appear in Fig. 11, and demonstrate that the rate of hydrogen production with a catalyst can increase 3 -fold in $80 \mathrm{~min}$ compared with the rate of hydrogen production without a catalyst.

Fig. 12 shows the volume of hydrogen produced using a catalyst under current densities 61,92 , and $123 \mathrm{~mA} / \mathrm{cm}^{2}$. The fastest production of hydrogen occurred using a catalyst synthesized at a current density of $92 \mathrm{~mA} / \mathrm{cm}^{2}$, 
followed by a catalyst synthesized with a current density of $123 \mathrm{~mA} / \mathrm{cm}^{2}$, while the slowest production used a the current density of $61 \mathrm{~mA} / \mathrm{cm}^{2}$. In general, a higher current density during catalyst synthesis equated to a greater content of $\mathrm{Ni}$ and $\mathrm{Co}$, which accelerated the hydrolysis reaction that produced hydrogen. The catalyst produced with a current density of $92 \mathrm{~mA} / \mathrm{cm}^{2}$ produced hydrogen faster than the catalyst with a current density of $123 \mathrm{~mA} / \mathrm{cm}^{2}$, because the latter example resulted in a catalyst amount that was so high it interfered with reactant transfer, which lowered the rate of hydrogen production.

Fig. 13 shows the volume of hydrogen produced at hydrolysis reaction temperatures of 300,313 , and $323 \mathrm{~K}$ using a catalyst produced under a current density of $92 \mathrm{~mA} / \mathrm{cm}^{2}$ for $60 \mathrm{~min}$. A higher temperature for hydrolysis reaction equaled at faster hydrolysis reaction for hydrogen production. This result agrees with the Arrhenius equation.

The volume of hydrogen that was generated was used to determine the reaction rate equation that determine the moles of $\mathrm{NaBH}_{4}$ that had reacted. The first-order reaction assumption was used to develop the reaction rate equation. Fig. 14 shows the relationship of the initial natural logarithmic of $\mathrm{NaBH}_{4}$ moles per mole of $\mathrm{NaBH}_{4}$ $\left(\ln \left(\mathrm{N}_{\mathrm{NaBH} 4,0} / \mathrm{N}_{\mathrm{NaBH} 4}\right)\right)$ used versus the hydrolysis reaction time on various catalysts with different current densities. The relationship shows a straight-line equation with $R^{2}>0.99$. This relationship shows that the first-order reaction assumption was accurate for the hydrolysis reaction equation. The reaction rate constants obtained ranged from $2.220 \cdot 10^{-3}$ to $3.864 \cdot 10^{-3} \mathrm{l} /(\mathrm{g} \cdot \mathrm{min})$.

Fig. 15 shows the relationship of $\ln \left(\mathrm{N}_{\mathrm{NaBH} 4,0}\left(\mathrm{~N}_{\mathrm{NaBH}}\right)\right.$ versus the hydrolysis reaction time at various temperatures. The relationship also shows a straight-line equation with $R^{2}$ approaching 1 , so the assumption of the order of the reaction was correct. The reaction rate constant ranged from $3.175 \cdot 10^{-3}$ to $14.117 \cdot 10^{-3} \mathrm{l} /(\mathrm{g} \cdot \mathrm{min})$.

The reaction rate constants at various temperatures were used to determine the Arrhenius equation. Fig. 16 shows the relationship of $\ln (k)$ versus $1 / T$ that was used to determine the Arrhenius equation. Based on this picture, the Arrhenius equation for this hydrolysis reaction is $k=6.5 \cdot 10^{-6} \cdot \exp (-6000 / T)$.

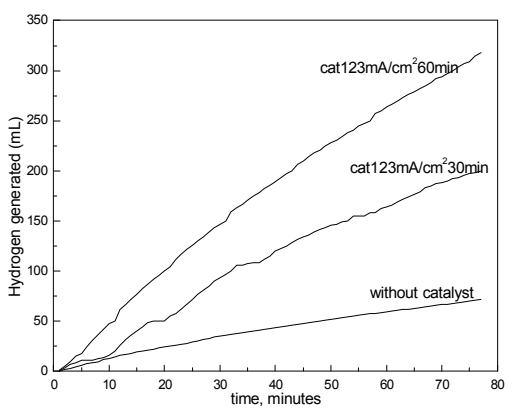

Fig. 11. The volume of hydrogen generated by electrolysis times of 30 and 60 minutes

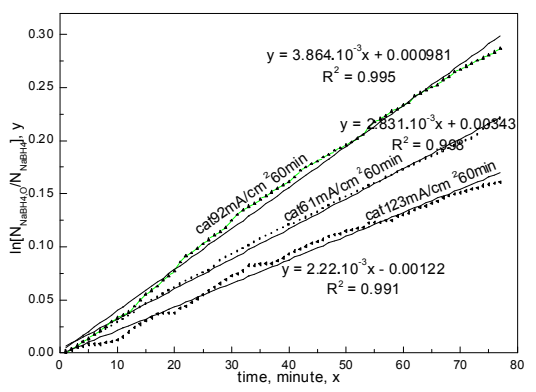

Fig. 14. Relationship of $\ln \left(\mathrm{N}_{\mathrm{NaBH} 4,0} / \mathrm{N}_{\mathrm{NaBH} 4}\right)$ vs. the hydrolysis reaction time on various catalysts with different current densities

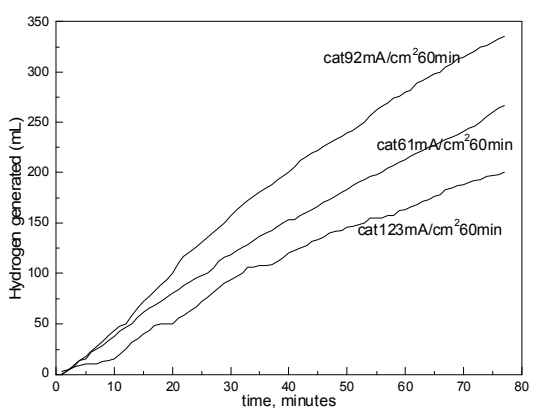

Fig. 12. Volume of hydrogen generated using a catalyst produced at various current densities

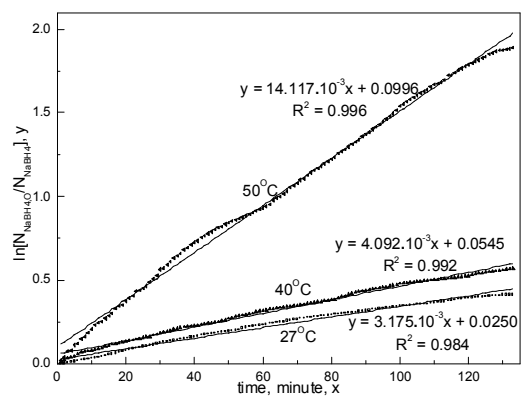

Fig. 15. Relationship of $\ln \left(\mathrm{N}_{\mathrm{NaBH} 4,0} / \mathrm{N}_{\mathrm{NaBH} 4}\right)$ vs. the hydrolysis reaction time at various temperatures

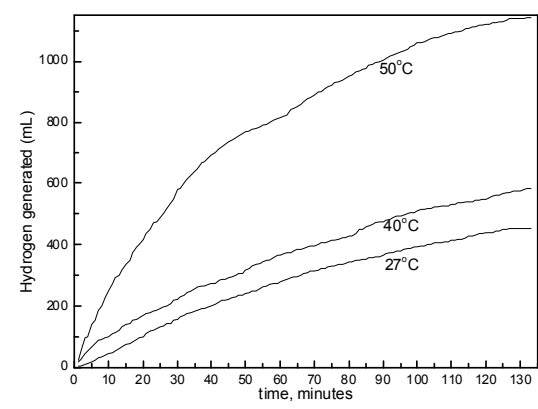

Fig. 13. Volume of hydrogen generated at various hydrolysis reaction temperatures using a catalyst produced under a current density of $92 \mathrm{~mA} / \mathrm{cm}^{2}$ for 60 minutes

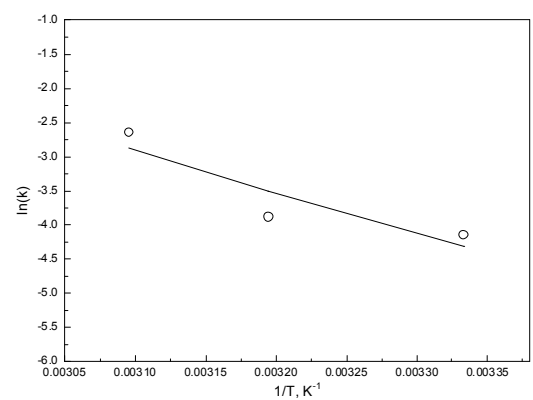

Fig. 16. Relationship of $\ln (k) v s .1 / T$ 


\section{Conclusions}

An electrochemical synthesis of $\mathrm{Ni}$ Co/hydroxyapatite catalyst was accomplished. The catalyst was tested for application to the hydrolysis of $\mathrm{NaHB}_{4}$, which generates hydrogen. The Ni$\mathrm{Co} /$ hydroxyapatite catalyst synthesis was carried out in electrochemical cells that were separated into two chambers via the use of a bipolar membrane. The $\mathrm{pH}$ of the solution in the anode chamber dropped rapidly to zero while the $\mathrm{pH}$ of the solution in the cathode chamber rose rapidly to 12 . Higher levels of current density resulted in faster decreases in the $\mathrm{pH}$ of the anode chamber, while in the cathode chamber the $\mathrm{pH}$ was increased at an accelerated rate. A low solution $\mathrm{pH}$ supported the formation of brushite in the anode chamber while a high $\mathrm{pH}$ solution resulted in the formation of HA in the cathode chamber. Testing of the Ni-Co/HA catalyst showed that longer durations of electrolysis of during catalyst formation resulted in an acceleration of the hydrolysis reaction with $\mathrm{NaBH}_{4}$ in the production of hydrogen. The highest rate of hydrogen production was obtained from the catalyst synthesized with the current density of $92 \mathrm{~mA} / \mathrm{cm}^{2}$. The $\mathrm{NaBH}_{4}$ hydrolysis reaction followed a first-order reaction with a reaction rate constant of $2.220 \cdot 10^{-3}$ to $14.117 \cdot 10^{-3} \mathrm{l} /(\mathrm{g} \cdot \mathrm{min})$. The Arrhenius equation for hydrolysis reactions at the temperatures from 300 to $323 \mathrm{~K}$ is $k=6.5 \cdot 10^{-6} \cdot \exp (-6000 / T)$.

\section{Acknowledgments}

We would like to thank the Directorate General of Higher Education (DGHE), the Ministry of Research, Technology and Higher, Indonesia, for funding through Penelitian Dasar Unggulan Perguruan Tinggi (PDUPT)2019Grant No. 718/UN27.21/PN/2019.

\section{References}

[1] Herrmann A, Mädlow A, Krause H.: Int. J. Hydrogen Energy, 2019, 44, 19061. https://doi.org/10.1016/j.ijhydene.2018.06.014 [2] Moriarty P., Honnery D.: Int. J. Hydrogen Energy, 2019, 44, 16029. https://doi.org/10.1016/j.ijhydene.2019.04.278

[3] Abe J., Popoola A., Ajenifuja E., Popoola O.: Int. J. Hydrogen Energy, 2019, 44,15072. https://doi.org/10.1016/j.ijhydene.2019.04.068
[4] Kojima Y.: Int. J. Hydrogen Energy, 2019, 44, 18179. https://doi.org/10.1016/j.ijhydene.2019.05.119

[5] Zhong H., Ouyang L., Ye J. et al.: Energy Storage Mater., 2017, 7, 222. https://doi.org/10.1016/j.ensm.2017.03.001

[6] Ali N., Yahya M., Mustafa N. et al.: Int. J. Hydrogen Energy, 2019, 44, 6720. https://doi.org/10.1016/j.ijhydene.2019.01.149

[7] Wang Y., Li G., Wu S. et al.: Int. J. Hydrogen Energy, 2017, 42, 16529. https://doi.org/10.1016/j.ijhydene.2017.05.034

[8] Pei Z. Wei, Wu C., Bai Y. et al.: Int. J. Hydrogen Energy, 2017, 42, 14725. https://doi.org/10.1016/j.ijhydene.2017.04.124

[9] Seven F., Sahiner N.: J. Power Sources, 2014, 272, 128. https://doi.org/10.1016/j.jpowsour.2014.08.047

[10] de Vasconcelos B., Minh D., Nzihou P.:Catal. Today, 2018, 310, 107. https://doi.org/10.1016/j.cattod.2017.05.092

[11] Malpica-Maldonado J., Melo-Banda J., Martínez-Salazar A. et al.: Int. J. Hydrogen Energy, 2019, 44, 12446.

https://doi.org/10.1016/j.ijhydene.2018.08.152

[12] Nur A., Jumari A., Budiman A. et al.: MATEC Web of Conferences. 2018, 156, 05015.

https://doi.org/10.1051/matecconf/201815605015

Received: August 28, 2019 / Revised: October 02, 2019 /

Accepted: February 02, 2020

\section{ЕЛЕКТРОСИНТЕЗ Ni-Со/ГІДРОКСИАПАТИТУ - КАТАЛІЗАТОРА ДЛЯ ВИРОБНИЦТВА ВОДНЮ - ГІДРОЛІЗОМ ВОДНОГО РОЗЧИНУ БОРОГІДРІДУ HATPIЮ $\left(\mathrm{NABH}_{4}\right)$}

Анотація. Електрохімічним методом синтезований каталізатор $\mathrm{Ni}$-Со на основі гідроксиапатиту для виробництва водню з $\mathrm{NaBH}_{4}$. Показано, що електрохімічна комірка складається з джерела жсилення постійного струму, карбонового анода і катода, $і$ біполярної мембрани для розділення комірки на дві камери. Процес проводили за густини струму 61, 91 та $132 \mathrm{мA} / \mathrm{cm}^{2}$ та тривалості електролізу 30, 60 та 90 хвилин. Проведено аналіз отриманих частинок за допомогою рентгенівської дифракиї та скануючої електронної мікроскопії. Встановлено, що збільшення тривалості електролізу для утворення каталізатора $\mathrm{Ni}$-Co/HA позитивно корелюється зі швидкістю реакиії гідролізу $\mathrm{NaBH}_{4}$ для виробництва водню. Встановлено, що найбільший вихід водню досягається за щільності струму $92 \mathrm{мA} / \mathrm{cm}^{2}$. Визначено, щзо реакиія гідролізу $\mathrm{NaBH}_{4}$ є реакиією першого порядку з постійною швидкістю реакиії $(2,220-14,117) \cdot 10^{-3} \pi /(2 \cdot x 8)$. Показано, щзо рівняння Арреніуса для реакиій гідролізу за температури від зо0до 323 К має вигляд $k=6,5 \cdot 10^{-6} \cdot \exp (-6000 / T)$.

Ключові слова: $\mathrm{Ni}$-Co/zідроксиапатит, накопичення водню, синтез, електрохімічний метод, біполярна мембрана. 